\title{
Possible Recycling of End-of-Life Dolomite Refractories by the Production of Geopolymer-Based Composites: Experimental Investigation
}

\author{
E. Furlani ${ }^{1}$ (D) A. Rondinella ${ }^{1} \cdot$ E. Aneggi ${ }^{1} \cdot$ S. Maschio ${ }^{1}$
}

Received: 19 February 2021 / Accepted: 26 May 2021 / Published online: 9 June 2021

(c) The Author(s) 2021

\begin{abstract}
Production and characterization of geopolymers prepared by mixing metakaolin, end-of-life dolomite refractories, sodium silicate solution, and sodium hydroxide solution have been performed. The as-received refractory was crumbled in order to obtain products having, respectively, $250 \mu \mathrm{m}, 1 \mathrm{~mm}$, and $2.5 \mathrm{~mm}$ maximum particles size. Each batch of powder was added in different proportions to a blank geopolymeric matrix. It has been observed that the addition of waste refractory reduces workability of the reference refractory-free slurry. After hardening, only the set of samples prepared with powders with maximum size of $250 \mu \mathrm{m}$ maintain integrity while the others resulted affected by the presence of fractures caused by volumetric instabilities; samples with composition R100 showed the highest compressive strength, whereas higher refractory addition lowers strength. Specific surface area appears independent by materials composition; conversely pore volume slightly increases with the addition of dolomite refractory powder. During the thermodilatometric tests all compositions display a shrinkage of about $0.1 \%$ between 170 and $400{ }^{\circ} \mathrm{C}$; however, sintering starts at higher temperature (above $600{ }^{\circ} \mathrm{C}$ ) and samples melt in the range between 650 and $750{ }^{\circ} \mathrm{C}$ as a function of their composition, thus showing that the resulting materials loose refractoriness with respect to both the reference geopolymer and the dolomite refractory.
\end{abstract}

\section{Graphical Abstract}

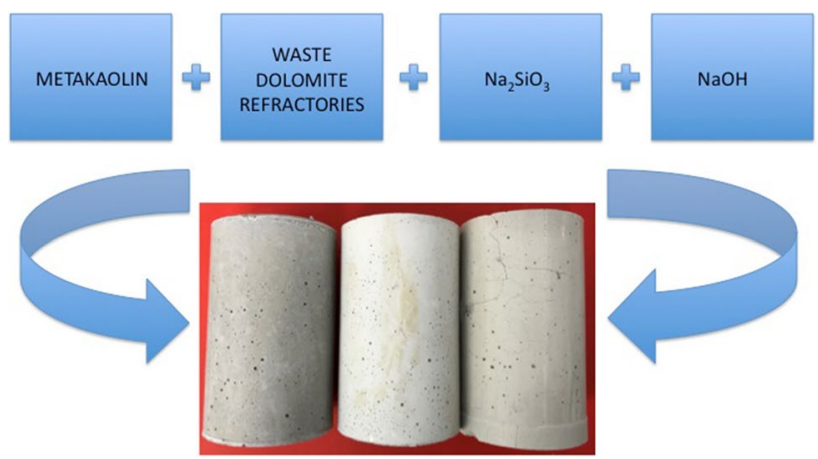

Keywords Geopolymers · End-of-life dolomite refractories · Compressive strength · Pore size distribution · Thermodilatometry

The contributing editor for this article was João António Labrincha Batista.

\section{E. Furlani \\ erika.furlani@uniud.it}

Extended author information available on the last page of the article

\section{Introduction}

Alkali-activated geopolymers (AAG) are generally known as novel hydraulic binder which can be prepared by alkali-activated aluminosilicate powders to replace Ordinary Portland Cement (OPC) in the manufacturing 
of engineering structures [1-8]. As a possible alternative application, it has been demonstrated that entrapment into a geopolymeric network of many hazardous compounds from inorganic waste or polluted products [9-11] can limit their release; in this context, they can be used to recycle fly ashes [12-18] or inertize some industrial by-products [19-25] thus showing a possible way which could permit to avoid their landfill disposal.

Dolomite refractories are often used in many steel production plants; in particular, they are used in the construction of basic oxide (BOF) and electric arc furnaces (EAF), but also in the building of ladle or other plants' hot parts. At the end of their life, waste refractory products are generally disposed of in landfill due to their high amount of $\mathrm{CaO}$ - and $\mathrm{MgO}$-containing compounds. In fact, their chemical composition causes volumetric instabilities which are a great disadvantage when exhaust dolomite refractories are used as a raw material for possible recycling. In fact, it is generally known that free $\mathrm{CaO}$ and $\mathrm{MgO}$ transform into hydroxides and carbonates under environmental conditions. In addition, $\mathrm{CaO}$ - or $\mathrm{MgO}$-containing compounds suffer of retarded hydration which, in general, occurs when materials produced are in use; for example, when recycling concerns the production of mortars or concretes, the resulting hardened materials could suffer of progressive mechanical decay. The above phenomena could be amplified when $\mathrm{CaO}-$ and $\mathrm{MgO}-$ containing compounds are not in the form of fine powders, but their feature consists of granulated products. As a consequence, their use in the production of cement-based materials or in the manufacturing of roads or streets must be limited to very little quantities or require severe treatments before recycling as it has been clearly demonstrated by several research papers [26-34].

In order to avoid landfill disposal, in the present research, the possibility to recycle waste dolomite refractories into the production of geopolymer-based materials has been explored. The influence of particles size distribution of waste refractories on the performances of the resulting materials was studied.

The thermodilatometric behavior of the resulting materials was also investigated in order to evaluate the temperature range for their possible application.

\section{Experimental Procedures}

\section{Starting Materials}

Argical M1200 calcined kaolin (metakaolin-MK) received from Imerys Refractory Minerals was used as a $\mathrm{SiO}_{2}$ and $\mathrm{Al}_{2} \mathrm{O}_{3}$ source for the geopolymeric network formation. Such powder was mixed with a commercial sodium silicate solution, containing 58 wt.\% of water with 2.23 wt. $\% \mathrm{SiO}_{2} / \mathrm{Na}_{2} \mathrm{O}$ ratio (2.29 molar). Such characteristics are typical of generally available commercial products of moderate cost. The above mixture was activated by an $8 \mathrm{M} \mathrm{NaOH}$ solution prepared using sodium hydroxide pellets $98 \%$ (Titolchimica Spa-Pontecchio Polesine, Ro-IT). Such products were mixed in the required proportion following the route described in a previous paper [35]; the resulted hardened geopolymer, having the $\mathrm{Si} /$ $\mathrm{Al}, \mathrm{Al}_{2} \mathrm{O}_{3} / \mathrm{Na}_{2} \mathrm{O}$, and $\mathrm{H}_{2} \mathrm{O} / \mathrm{Na}_{2} \mathrm{O}$ ratios of $1.63,1.5$, and 15.3 , respectively, was used as the reference composition also in the present research.

The above blank composition was then added with different proportions of waste dolomite refractories. Such waste materials were received in the form of a granulated, wet product containing $11 \mathrm{wt} . \%$ of water. The presence of water is due to a previous weathering which was made by the producer to ease transport to its final landfill destination. The as-received material was dried in an oven at $100{ }^{\circ} \mathrm{C}$ for $24 \mathrm{~h}$, transformed into a coarse powder by milling, and then shared into three parts: the first containing particles with maximum size of $250 \mu \mathrm{m}$, the second and the third with particles with maximum sizes of 1.0 $\mathrm{mm}$ and $2.5 \mathrm{~mm}$, respectively. Each batch was used to prepare a complete set of geopolymer-based materials.

Chemical composition obtained by means of a Spectro Mass 2000 Induced Coupled Plasma (ICP) mass spectrometer and density determined following the EN993-1 standard of the as-received waste dolomite refractory are reported in Table 1.

The cumulative particle size distribution (PSD) of the product with maximum particles size of $2.5 \mathrm{~mm}$ was made by means of standard sieves, whereas those of the powders with maximum particles size of $1 \mathrm{~mm}$ and $250 \mu \mathrm{m}$, respectively, were acquired in water by an Horiba LA950 laser scattering particle size analyzer. Curves are displayed with logarithmic abscissa.

X-ray diffraction patterns, collected by a step size of $0.02^{\circ}$ in the range $10^{\circ}-80^{\circ}$ and counting period of $40 \mathrm{~s}$ per angular abscissa, were obtained by a Philips X'Pert diffractometer at $40 \mathrm{kV}$ and $40 \mathrm{~mA}$ using a $\mathrm{Cu}-\mathrm{K} \alpha$ (Ni filtered) radiation. X'Pert

Table 1 Chemical composition, reported in term of oxides, of the as-received waste dolomite refractory product

\begin{tabular}{lllllllllll}
\hline & $\mathrm{MgO}$ & $\mathrm{CaO}$ & $\mathrm{SiO}_{2}$ & $\mathrm{Fe}_{2} \mathrm{O}_{3}$ & $\mathrm{Al}_{2} \mathrm{O}_{3}$ & $\mathrm{Cr}_{2} \mathrm{O}_{3}$ & $\mathrm{P}_{2} \mathrm{O}_{5}$ & $\mathrm{MnO}$ & Others & Density $\left(\mathrm{g} \mathrm{cm}^{-3}\right)$ \\
\hline $\mathrm{Wt} \%$ & 58.1 & 33.5 & 2.1 & 0.9 & 1.4 & 0.2 & 1.5 & 0.2 & 2.0 & 2.60 \\
\hline
\end{tabular}


HighScore software (Philips) was used for phase identification [36].

ATR-FTIR analysis was performed on the as-received materials as well as on hardened geopolymeric samples to investigate their chemical composition. A Nicolet iS ${ }^{\mathrm{TM}} 50$ FT-IR Fourier transform spectrometer was employed using the Attenuated Total Reflection (ATR) method. Each IR spectrum was acquired using a $2 \mathrm{~cm}^{-1}$ resolution in a spectral window ranging from 500 to $4000 \mathrm{~cm}^{-1}$ with 100 scans.

\section{Samples Preparation}

The mix proportion design, referred to $100 \mathrm{~g}$ of $\mathrm{MK}$, is reported in Table 2 together with sample identification symbolic names. Table also reports $\mathrm{H}_{2} \mathrm{O} /$ total solid content ratios of the materials prepared. Mixing was performed by a Hobart stirrer (5 L capacity). It must be also remarked that, for each composition (namely R100, R200, and R300) were prepared samples containing powdered waste refractory with different maximum particles dimension.

The production protocol, after several attempts, was set up as follows: in the first step, the basic geopolymeric paste was produced and mixing was protracted until reaching a sufficient fluidity (15 min mixing); at that time the powdered refractory was added in the required proportion and mixing was maintained for 15 additional minutes. At the end of homogenization, slurries were poured into high-density cylindrical moulds, vibrated for $2 \mathrm{~min}$ in order to maximize air removal, and sealed by a plastic film.

In order to evaluate workability, the following modified spread-flow test has been pointed out [37, 38]: slurries were poured into a truncated conical mould (top diameter $=70 \mathrm{~mm}$, bottom diameter $r=100 \mathrm{~mm}$, height $=60 \mathrm{~mm}$ ), which was filled up to the top; it was then lifted vertically after $1 \mathrm{~min}$ and the diameter of the paste after spreading was measured along two perpendicular directions. The slump value was derived from the average of the two measurements.

After casting, geopolymeric pastes were maintained into the moulds at room temperature for $24 \mathrm{~h}$ and then

Table 2 Mix proportion design of the compositions prepared referred to $100 \mathrm{~g}$ of metakaolin (MK)

\begin{tabular}{lrrlll}
\hline $\begin{array}{l}\text { Sample } \\
\text { name }\end{array}$ & MK $(\mathrm{g})$ & $\mathrm{R}(\mathrm{g})$ & $\begin{array}{l}\text { Sodium } \\
\text { silicate } \\
\text { solution } \\
(\mathrm{g})\end{array}$ & $\begin{array}{l}\text { Na hydrox- } \\
\text { ide solu- } \\
\text { tion }(\mathrm{g})\end{array}$ & $\begin{array}{l}\mathrm{H}_{2} \mathrm{O} / \text { total } \\
\text { solid content }\end{array}$ \\
\hline $\mathrm{R} 0$ & 100 & 0 & 110 & 20 & 0.54 \\
$\mathrm{R} 100$ & 100 & 100 & 110 & 20 & 0.32 \\
$\mathrm{R} 200$ & 100 & 200 & 110 & 20 & 0.23 \\
$\mathrm{R} 300$ & 100 & 300 & 110 & 20 & 0.175 \\
\hline
\end{tabular}

Waste Dolomite Refractory $=\mathrm{R}$ cured at $60{ }^{\circ} \mathrm{C}$ for further $24 \mathrm{~h}$. Successively, they were removed from the moulds, sealed again by a plastic film, and maintained at room temperature and pressure for 7 days before being used for characterization and testing.

\section{Characterization of Hardened Materials}

Material's compressive strength was determined on cylindrical specimens with $60 \mathrm{~mm}$ diameter and $120 \mathrm{~mm}$ height with a crosshead speed of $2 \mathrm{~mm} \mathrm{~min}^{-1}$; data were averaged over five measurements for each composition in agreement with the ASTM C39 standard; measurements were performed by an 810 Material Test System.

Open porosity of the hardened samples was accessed by water absorption measurements. Investigations were made following a modified ASTM C 642 standard procedure on cylindric samples with diameter and height of $20 \mathrm{~mm}$. In order to perform this tests, hardened samples were first dried at $80 \pm 5^{\circ} \mathrm{C}$ for $24 \mathrm{~h}$ and weighed in air. This measurement leads to determine samples dry weight $\left(W_{1}\right)$; in a second time, each sample was treated in an autoclave at $120^{\circ} \mathrm{C}$ and $2 \mathrm{kPa}$ for $2 \mathrm{~h}$ using $2 \mathrm{~L}$ of water, cooled down to room temperature (in water), dried with a cloth and weighed again: this measurements leads to determine its wetted weight $\left(W_{2}\right)$. Material's water absorption, which in turn can be assumed also as open porosity, was evaluated according to the following equation:

$\mathrm{W}(\%)=100\left(\mathrm{~W}_{2}-\mathrm{W}_{1}\right) / \mathrm{W}_{1}$.

In accordance to the BET method, a Tristar 3000 gas adsorption analyzer (Micromeritics) was used to investigate specific surface areas and pore size distribution of the hardened materials on parts resulted from compressive strength tests; tests were made by nitrogen adsorption at $77^{\circ} \mathrm{K}$.

Thermodilatometric tests were carried out in air, by a Netzsch alumina dilatometer, at a heating rate of $10{ }^{\circ} \mathrm{C} \mathrm{min}{ }^{-1}$ up to the softening temperature on cylindric samples $(\Phi=3 \mathrm{~mm}$ and length $=25 \mathrm{~mm})$. For this set of experiments, due to the small diameter of the samples, only geopolymers containing powders with maximum size of $250 \mu \mathrm{m}$ were tested. During dilatometric tests, at the end of the shrinkage, samples collapse, and at that moment, tests were stopped. The collapsing temperature was assumed as the material's softening temperature. The part of the thermodilatometric diagrams, relative to the softening temperatures, is not reported in the present paper because, in order to preserve dilatometer integrity from the aggression of the liquid, the experiment was stopped a few degrees before the final temperature. 


\section{Results and Discussion}

The characterization of the as-received MK has been already described in a previous paper [35] and not repeated here. It should be remarked the presence of muscovite $\left(\mathrm{K}_{2} \mathrm{Al}_{4}\left(\mathrm{Si}_{6} \mathrm{Al}_{2} \mathrm{O}_{20}\right)(\mathrm{OH})_{4}\right)$ and anatase $\left(\mathrm{TiO}_{2}\right)$ as additional phases to the amorphous metakaolinite. On the other hand, the present manuscript reports chemical and crystallographic characteristics of the waste dolomite refractories (R). As reported in Table 1, the main components of $\mathrm{R}$ are $\mathrm{MgO}$ and $\mathrm{CaO}$ which are the typical major compounds of dolomite refractories, $\mathrm{Fe}_{2} \mathrm{O}_{3}$ and $\mathrm{MnO}$ represent impurities deriving from steel production, whereas $\mathrm{SiO}_{2}, \mathrm{Al}_{2} \mathrm{O}_{3}$, and $\mathrm{P}_{2} \mathrm{O}_{5}$ are reasonably due to the binders which have been used for manufacturing the hot parts of steel production plants, i.e., refractory walls $[39,40]$.
The XRD investigation (Fig. 1), in agreement with data of Table 1, confirmed the presence of free periclase (MgO, PDF 01-087-0651), portlandite $\left(\mathrm{Ca}(\mathrm{OH})_{2}\right.$, PDF 01-084-1276), calcite $\left(\mathrm{CaCO}_{3}\right.$, PDF 01-086-0174), mullite $\left(3 \mathrm{Al}_{2} \mathrm{O}_{3} 2 \mathrm{SiO}_{2}\right.$, PDF 01-079-1456), cordierite $\left(\mathrm{Mg}_{2} \mathrm{Al}_{4} \mathrm{Si}_{5} \mathrm{O}_{18}\right.$, PDF 01-0871964), and aluminum phosphate $\left(\mathrm{Al}\left(\mathrm{PO}_{3}\right)_{3}\right.$, $\mathrm{PDF}$ 01-0700104) together with some minor quantities of other hydrated compounds such as brushite $\left(\mathrm{CaHPO}_{4} \cdot 2\left(\mathrm{H}_{2} \mathrm{O}\right)\right.$, PDF 00-011-0293) and pyroaurite $\left(\mathrm{Mg}_{6} \mathrm{Fe}_{2} \mathrm{CO}_{3}(\mathrm{OH})_{16} \cdot 4 \mathrm{H}_{2} \mathrm{O}\right.$, PDF 01-086-0181). The pattern displayed in Fig. 1 has been obtained on powders with maximum particles size of $250 \mu \mathrm{m}$, however, the two slots of powders with greater particles showed similar feature thus revealing an almost homogeneous crystallographic composition of the three batches of powders.

Figure 2a, b shows the cumulative particle size distribution trend of the three batches of powders. Figure 2a shows the results obtained on the product with maximum particles

Fig. 1 X-ray diffraction pattern of the as-received powdered waste dolomite refractory. Phases are identified with the following symbols: (open circle $)=\mathrm{MgO}$; $($ open triangle $)=\mathrm{Ca}(\mathrm{OH})_{2} ;($ closed triangle $)=\mathrm{Ca}(\mathrm{CO})_{3} ;($ closed square $)=3 \mathrm{Al}_{2} \mathrm{O}_{3} 2 \mathrm{SiO}_{2}$; (closed dia-

mond) $=\mathrm{Mg}_{2} \mathrm{Al}_{4} \mathrm{Si}_{5} \mathrm{O}_{18}$; (open square $)=\mathrm{CaHPO}_{4} \cdot 2\left(\mathrm{H}_{2} \mathrm{O}\right)$; (open diamond) $=\mathrm{Al}\left(\mathrm{PO}_{3}\right)_{3}$; (closed cir-

cle $)=\mathrm{Mg}_{6} \mathrm{Fe}_{2} \mathrm{CO}_{3}(\mathrm{OH})_{16} 4 \mathrm{H}_{2} \mathrm{O}$

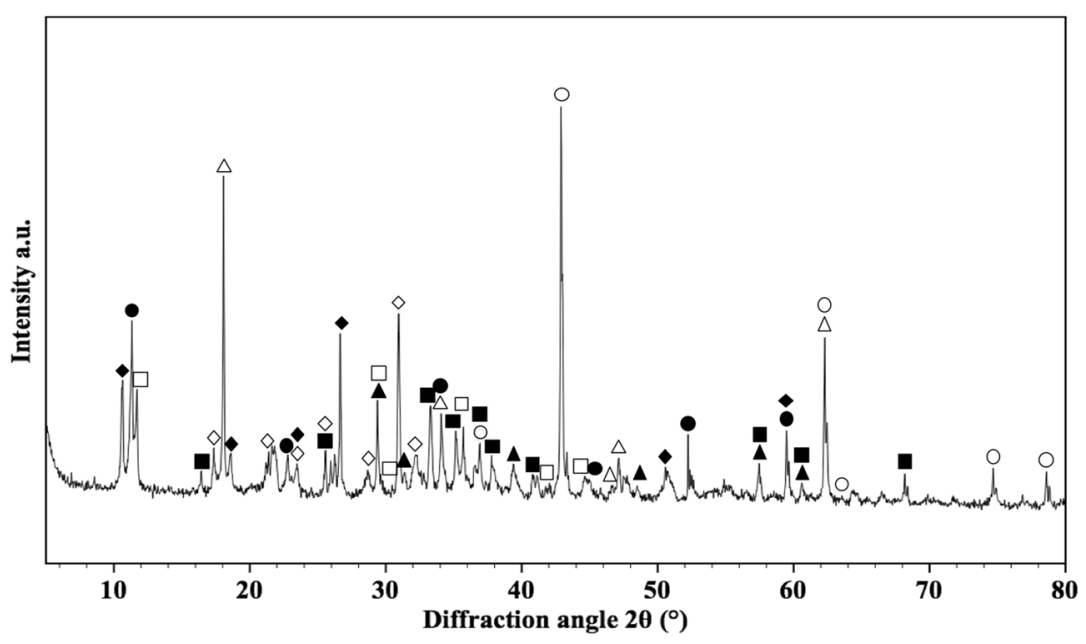

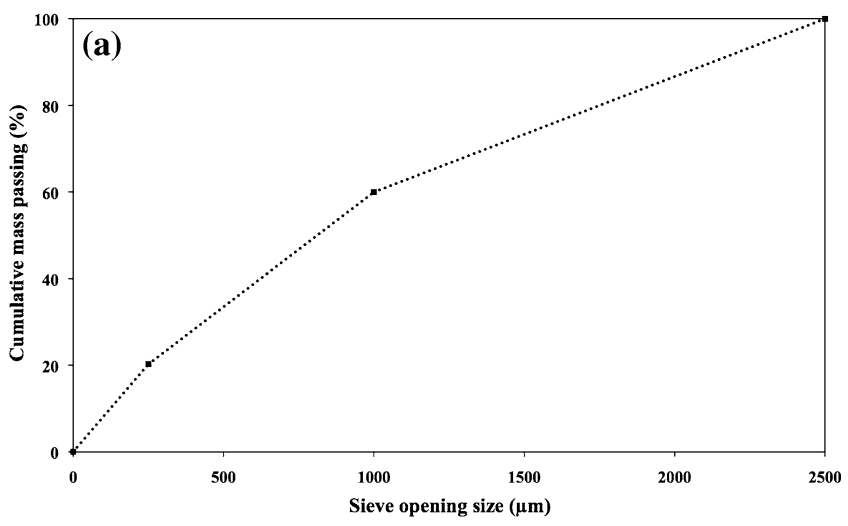

Fig. 2 a, b Particle size distribution (cumulative representation) of the three batches of powdered waste refractory: a obtained on the product with maximum particles size of $2.5 \mathrm{~mm}$; b curves of the

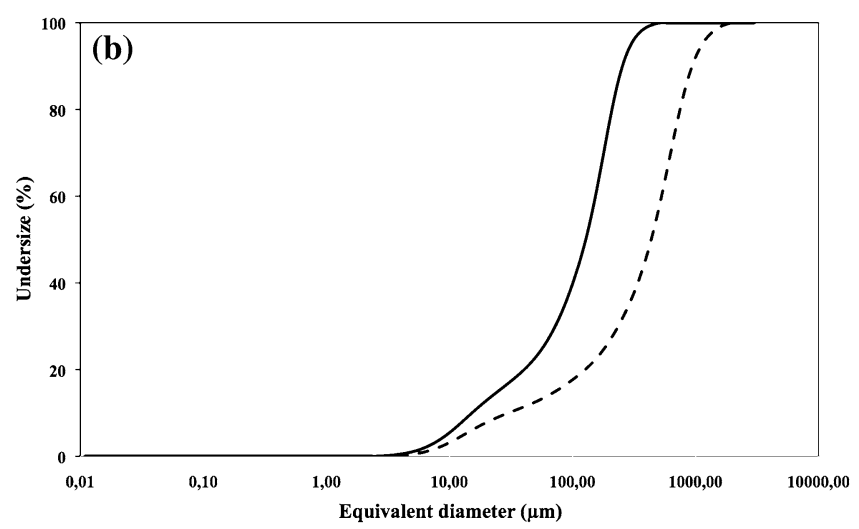

batches with maximum particles size of 250 (plain line) and $1000 \mu \mathrm{m}$ (dashed line), respectively 
size of $2.5 \mathrm{~mm}$ and was obtained by standard sieves, whereas Fig. $2 b$ displays the curves of the two batches of powders with maximum particles size of 250 (plain line) and $1000 \mu \mathrm{m}$ (dashed line), respectively, and was obtained by the laser particles size analyzer. It can be observed that the powder with maximum size of $2.5 \mathrm{~mm}$ contains about $20 \%$ of particles having size lower than $250 \mu \mathrm{m}$ and about $40 \%$ of particles with size greater than $1000 \mu \mathrm{m}$; on the other hand, the $\mathrm{d}_{50}$ of the powders with maximum size of $250 \mu \mathrm{m}$ and $1000 \mu \mathrm{m}$ are 125 and $435 \mu \mathrm{m}$, respectively.

The mix proportion design of the materials prepared in the present research, reported in Table 2, shows that the addition of $\mathrm{R}$ lowers the $\mathrm{H}_{2} \mathrm{O}$ /total solid content of the different compositions. This ratio affects pastes workability, independently on the particles size distribution of the R powders used for materials preparation as confirmed by Fig. 3, which shows that the addition of $\mathrm{R}$ reduces the slump flow. In particular, it can be observed that the slurry corresponding to the blank composition has a slump flow of $155 \mathrm{~mm}$; this value reaches the minimum level in the compositions of R300 which show a value close to the diameter of the truncated cone used for this test. Therefore, R300 has been established as the composition with the workability limit. Geopolymer-based materials containing greater quantity of $\mathrm{R}$ than the composition R300 were not prepared because components homogenization and pastes casting were not possible with the instruments available in our laboratories.

Figure 4 shows three hardened cylindrical specimens with composition R300 made with R having particles of 250 , 1000 , and $2500 \mu \mathrm{m}$, respectively. In particular, it is observed that sample containing $\mathrm{R}$ particles with maximum size of $250 \mu \mathrm{m}$ looks undamaged, the one made with $\mathrm{R}$ particles of $1000 \mu \mathrm{m}$ shows the presence of some chipping (indicated by arrows), whereas that containing R particles of $2500 \mu \mathrm{m}$ exhibits extended fractures [26, 30, 32, 33]. Therefore, the set of samples made with damaged products were not furtherly characterized. It can also be observed that all these

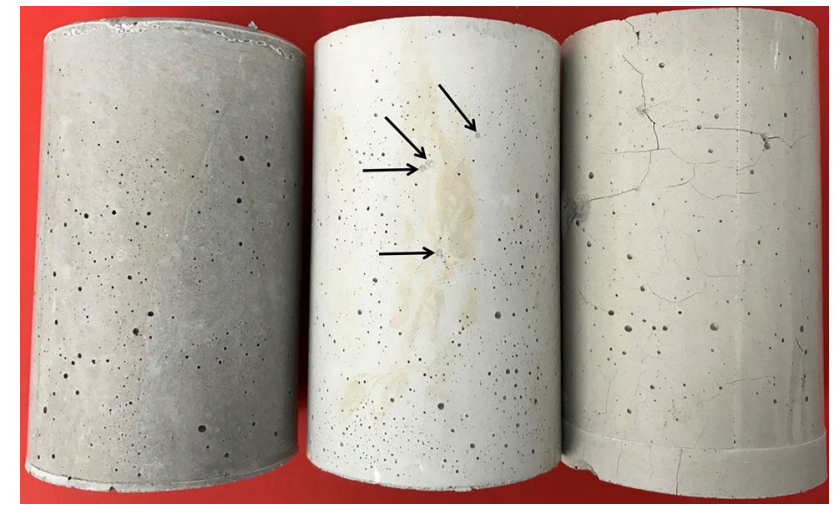

Fig. 4 Image of the samples with composition R300 made with the three batches of powdered waste refractory. Detailing, from left to right, $\mathrm{R}$ with maximum size of 250,1000 , and $2500 \mu \mathrm{m}$, respectively. Arrows indicate some visible chipping

three specimens show the presence of a significant amount of coarse open porosity which is reasonably caused by their low ratio of $\mathrm{H}_{2} \mathrm{O}$ /total solid content and low slump that limits pastes workability thus entrapping a large quantity of air during homogenization.

Figure 5 compares the XRD patterns acquired on the mixture of powders containing $50 \mathrm{wt} . \%$ of MK and $50 \mathrm{wt} . \%$ of $\mathrm{R}$ before geopolymerization (top) with the one acquired on the geopolymer with composition R300 (bottom). Such comparison enables evaluation of the possible partial reaction of some starting components during the geopolymer production.

It has been observed that the intensity of peaks at $9.0^{\circ}$, $17.6^{\circ}$, and $19.8^{\circ}$ (corresponding to the muscovite phase of MK) appear sensibly reduced in the geopolymer with respect to the unreacted powders mixture. This is in agreement with literature $[7,12,16-18,20-23,35]$ which clearly state the reactivity of silica and most of aluminosilicate compounds during geopolymerization.
Fig. 3 Slump flow versus materials composition: the plain line is referred to pastes containing the $\mathrm{R}$ with maximum size of $250 \mu \mathrm{m}$, whereas dashed and dotted lines are referred to the pastes made with $\mathrm{R}$ having maximum size of 1000 and $2500 \mu \mathrm{m}$, respectively

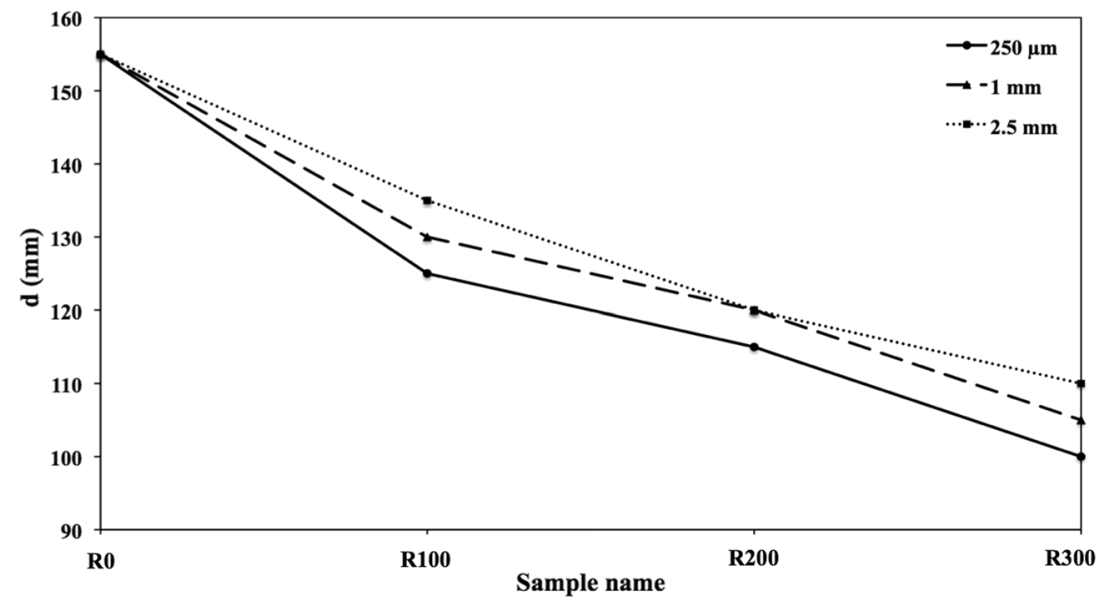




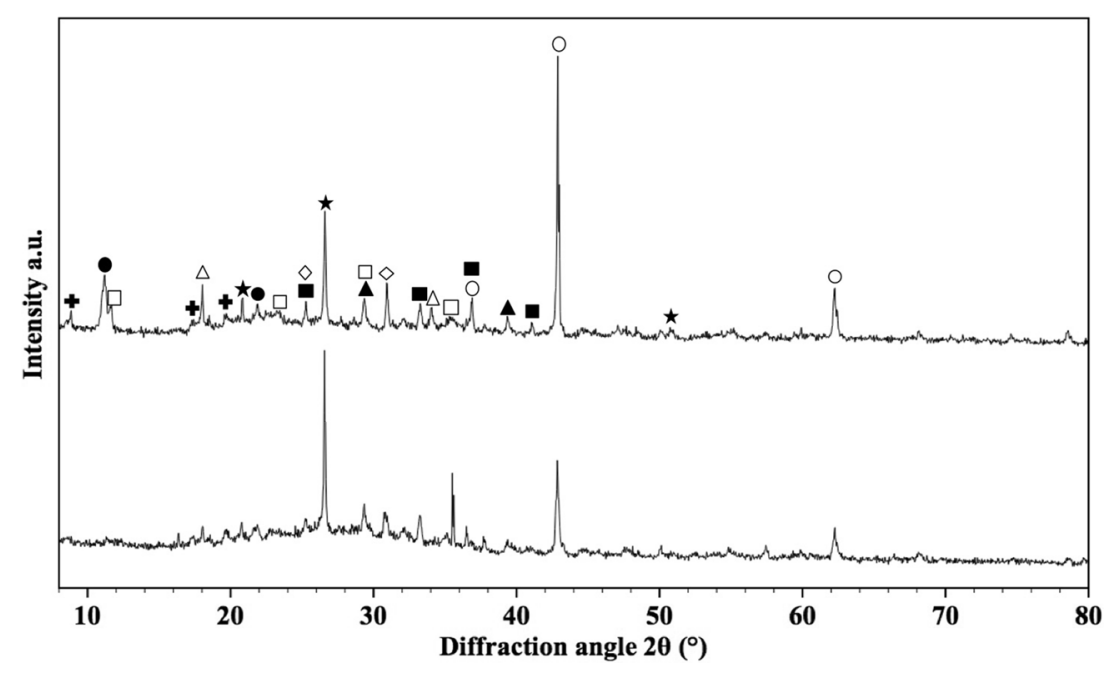

Fig. 5 X-ray diffraction patterns, acquired on the mixture of powders containing $50 \%$ wt of $\mathrm{MK}$ and $50 \%$ wt of $\mathrm{R}$ (i.e., R300), before (top) and after (bottom) geopolymerization. Phases are identified with the following symbols: (closed star $=\mathrm{SiO}_{2}$ (quartz); (closed plus) $=\left(\mathrm{K}_{2} \mathrm{Al}_{4}\left(\mathrm{Si}_{6} \mathrm{Al}_{2} \mathrm{O}_{20}\right)(\mathrm{OH})_{4}\right)$ (muscovite); (closed cir-

Reduced intensities after the geopolymer production are observed in peaks from pyroaurite $\left(11.3^{\circ}\right.$ and $\left.22.7^{\circ}\right)$, brushite $\left(11.7^{\circ}\right.$ and $\left.23.4^{\circ}\right)$, portlandite $\left(18.1^{\circ}, 34.1^{\circ}\right)$, and periclase $\left(42.9^{\circ}\right.$ and $\left.62.4^{\circ}\right)$ thus revealing that also these compounds are prone to react during the geopolymer production. On the other hand, quartz and calcium carbonate seem to behave as inert components as their peaks maintain similar intensity before and after geopolymerization.

In fact, literature clearly reports that the presence of $\mathrm{MgO}$ or $\mathrm{CaO}$ into a geopolymeric network could have beneficial effects on the properties of the hardened materials because their reactions limit material's shrinkage and refine the pore size distribution within the geopolymeric paste provided that the components used for materials preparation are in the form of fine powders [41-49]. However, it is reasonably expected that the presence of such compounds into coarse particles, being cause of uncontrolled instabilities, could generate fractures and chipping in hardened materials as it has been observed also in cement-based mortars containing coarse steel slag and therefore coarse $\mathrm{CaO}-$ and $\mathrm{MgO}-$ containing particles [32-34].

Figure 6 compares ATR-FTIR spectra from a geopolymer reference (black curve) with R300 sample before and after polymerization (blue and red curve, respectively). The band between 950 and $1200 \mathrm{~cm}^{-1}$ is attributed to $\mathrm{Si}-\mathrm{O}-\mathrm{Si}$ vibrations [16, 50-53]. The spectral position of this peak is strictly connected to the geopolymerization process. The chemical reaction leads to a shift toward lower wavenumbers in both "Reference" and "R300 Post-polymerization" samples. [16, 50-53]. Peaks at $1640 \mathrm{~cm}^{-1}$ and $3200 \mathrm{~cm}^{-1}$ are connected to the presence of $\mathrm{O}-\mathrm{H}$ bonds in adsorbed water cle $)=\mathrm{Mg}_{6} \mathrm{Fe}_{2} \mathrm{CO}_{3}(\mathrm{OH})_{16} 4 \mathrm{H}_{2} \mathrm{O} ; \quad($ open $\quad$ square $)=\mathrm{CaHPO}_{4} \cdot 2\left(\mathrm{H}_{2} \mathrm{O}\right)$; (open triangle) $=\mathrm{Ca}(\mathrm{OH})_{2} ; \quad$ (open circle) $=\mathrm{MgO}$; (closed square $)=3 \mathrm{Al}_{2} \mathrm{O}_{3} 2 \mathrm{SiO}_{2} ; \quad($ closed triangle $)=\mathrm{Ca}\left(\mathrm{CO}_{3}\right) ; \quad$ open diamond $)=\mathrm{Al}\left(\mathrm{PO}_{3}\right)_{3}$

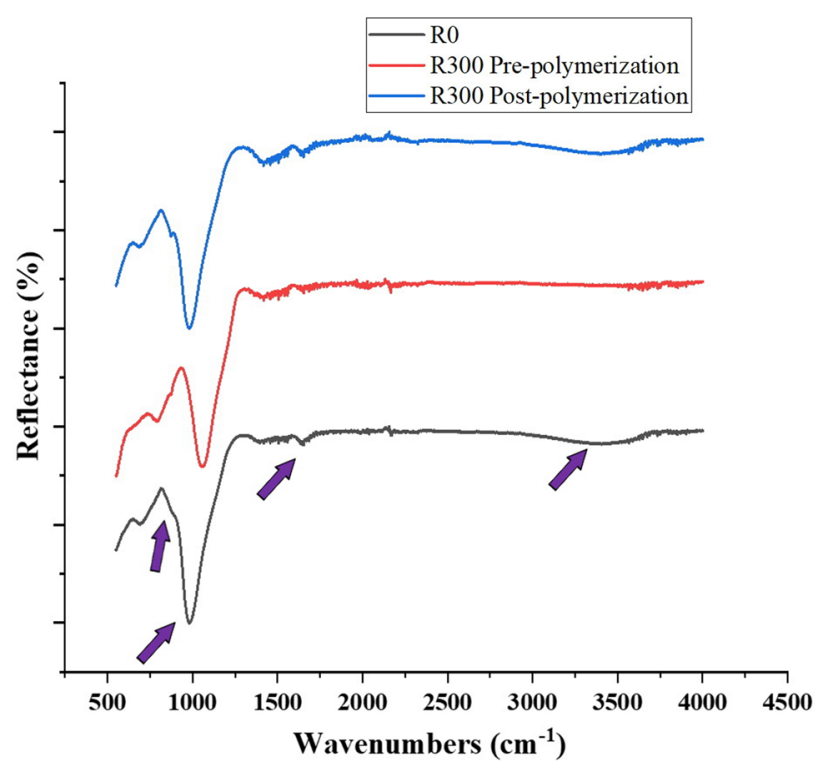

Fig. 6 ATR-FTIR spectra collected on a geopolymer reference, on a R300 sample before and after geopolymerization. The main vibrations are indicated by arrows

$[50,51]$. The weak bands at $\sim 870 \mathrm{~cm}^{-1}$ and $\sim 1450 \mathrm{~cm}^{-1}$ are related to the presence of carbonates [54]. The analysis of the FTIR spectra confirms XRD results and provides further insights about the chemistry of such geopolymers. In particular, the addition of refractories does not affect the chemical composition of the final geopolymer.

Figure 7 shows the trend of compressive strength versus materials composition of the samples made with $R$ 
Fig. 7 Compressive strength versus composition of the two sets of samples made with $\mathrm{R}$ having maximum size of $250 \mu \mathrm{m}$ (plain line) and $1000 \mu \mathrm{m}$ (dashed line), respectively (error bars are also reported)

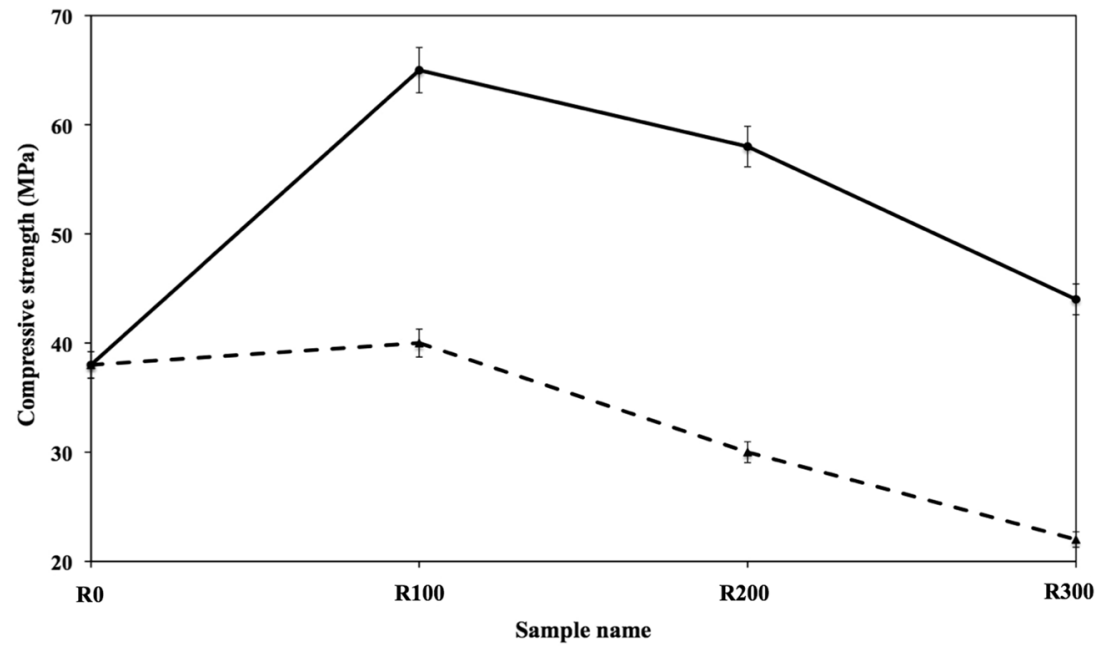

having maximum size of $250 \mu \mathrm{m}$ (plain line) and $1000 \mu \mathrm{m}$ (dashed line), respectively (error bars are also reported). It can be observed that both set of materials display the highest value at composition $\mathrm{R} 100$ and that higher $\mathrm{R}$ addition lower strength; in addition all samples prepared using $\mathrm{R}$ with maximum size of $250 \mu \mathrm{m}$ display higher strength compared to the control samples and to those containing $\mathrm{R}$ of greater size as it is already demonstrated by other authors [55].

Figure 8 reports water absorption versus composition of the samples prepared. The plain line refers to materials prepared with $\mathrm{R}$ powders having maximum size of $250 \mu \mathrm{m}$, whereas the dashed line refers to those obtained using $\mathrm{R}$ powders with maximum size of $1000 \mu \mathrm{m}$. The R-free control composition revealed water absorption of $24 \%$ which decreases in each set of materials for composition R100; higher $\mathrm{R}$ additions cause the increase of water absorption. However, the set of materials containing powders with maximum size of $250 \mu \mathrm{m}$ revealed values that remain inferior to one of the reference composition for any $\mathrm{R}$ addition, whereas those produced using powders with maximum size of $1000 \mu \mathrm{m}$ showed greater values.

Water absorption tests provide information about material's open porosity, i.e., great pores and defects which affect their mechanical performances. Nevertheless, water adsorption tests are useful to evaluate the homogeneity of the bulk material. It should be pointed out that samples with composition R100 are those with the highest strength and the lowest water absorption.

Figure 9 and Table 3 show the results obtained from pore size distribution and specific surface area investigations. It may be observed that all specific surface area data fall around $25 \mathrm{~m}^{2} \mathrm{~g}^{-1}$ and seem to be not affected by materials composition, whereas pore volume increases little with the addition of R. In parallel, pore size distribution of all the compositions range between the same limits ( 5 and $55 \mathrm{~nm}$ ) and shows maximum pores concentration at about $21 \mathrm{~nm}$ for all compositions; the quantity of pores having this size, increases with the addition of $\mathrm{R}$.
Fig. 8 Water absorption versus composition of the two sets of samples made with $\mathrm{R}$ having maximum sizes of $250 \mu \mathrm{m}$ (plain line) and $1000 \mu \mathrm{m}$ (dashed line), respectively

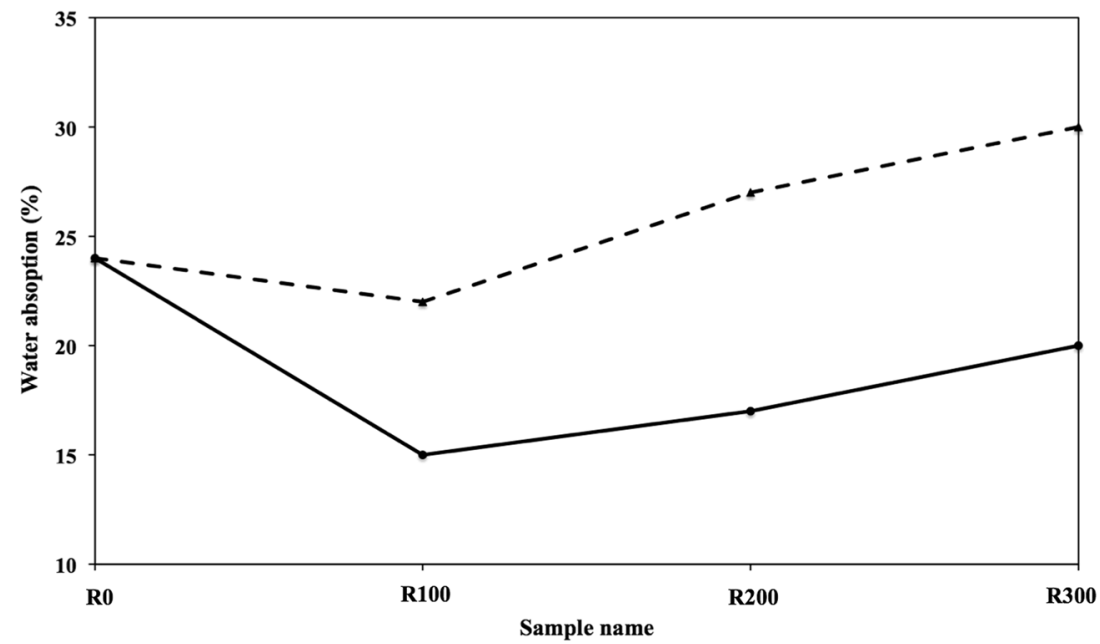


Fig. 9 Pore size distribution of geopolymeric samples with composition R0 (black), R100 (red), R200 (green), and R300 (yellow) (color figure online)

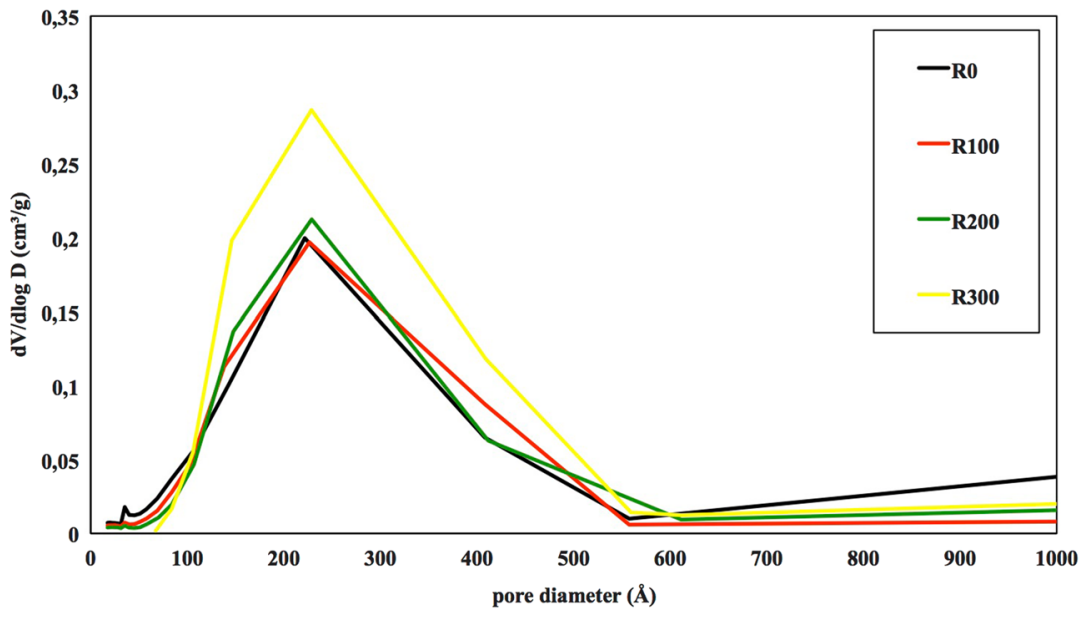

Table 3 Specific surface area $\left(\mathrm{m}^{2} \mathrm{~g}^{-1}\right)$ and pore volume $\left(\mathrm{cm}^{3} \mathrm{~g}^{-1}\right)$ of geopolymeric samples made with dolomite waste powder with maximum size of $250 \mu \mathrm{m}$

\begin{tabular}{lll}
\hline Sample & Surface area $\left(\mathrm{m}^{2} \mathrm{~g}^{-1}\right)$ & $\begin{array}{l}\text { Pore } \\
\text { Volume } \\
\left(\mathrm{cm}^{3} \mathrm{~g}^{-1}\right)\end{array}$ \\
\hline R0 & 26 & 0.110 \\
R100 & 24 & 0.107 \\
R200 & 24 & 0.112 \\
R300 & 26 & 0.190 \\
\hline
\end{tabular}

However, material's mechanical behavior is related, but not intrinsically linked to the nanosized porosity when the microstructure also contains a large quantity of micro and macroporosity. In our experimental investigation, the relation between mechanical strength and materials water absorption appears much more evident since it is observed as a great correlation between compressive strength and water absorption data.

Figure 10 is a stereoscopic light microscope photograph of a polished section of a sample with composition R300; it highlights the presence of several rounded holes which are reasonably due to air bubbles entrapped during production. It has been moreover observed that their amount appears to increase with the amount of $\mathrm{R}$ and therefore be directly related to pastes workability.

It is therefore possible to speculate that materials' nanoporosity plays a partial role on materials' mechanical behavior. It is the opinion of the authors of the present research that materials' macroporosity, i.e., the one which includes micro and millimetric porosity plays a much more important role. This type of porosity is due to the different water/total solid content of the starting compositions which affects their workability and therefore their air content during production and hardening $[33,38,56-58]$, in this way showing that

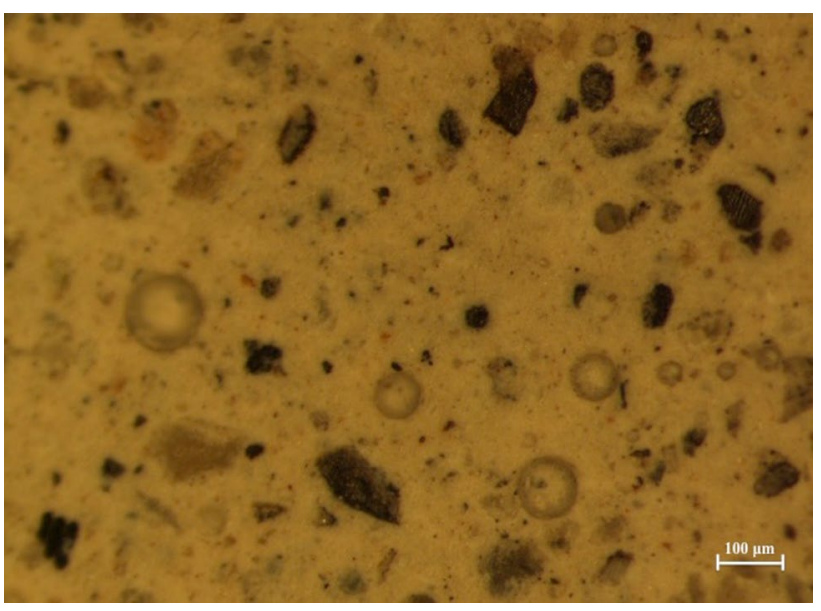

Fig. 10 Stereoscopic light microscope photograph of a polished section of a sample with composition R300; several rounded holes are visible

vibration is not sufficient to remove all the air entrapped into the pastes.

Figure 11 shows the semi-quantitative thermodilatometric behavior of the four specimens (i.e., R0, R100, R200, and R300), whereas the characteristic temperatures obtained during the thermodilatometric tests are reported in Table 4. It is observed that all compositions display an almost continuous shrinkage with increasing temperature, but display a significant length change between 170 and $400{ }^{\circ} \mathrm{C}$. In this range, it has been observed a shrinkage of about $0.1 \%$ independently on materials composition. The real sintering process starts at higher temperature (above $600{ }^{\circ} \mathrm{C}$ for all compositions) and then, in a restricted range, samples collapse and melt at temperatures ranging from 650 to $750{ }^{\circ} \mathrm{C}$ as a function of their composition. It must be remarked that the amount of $\mathrm{CaO}$ and $\mathrm{MgO}$, generally known as blasting compounds, which is improved by enlarging the quantity of $\mathrm{R}$ into the 


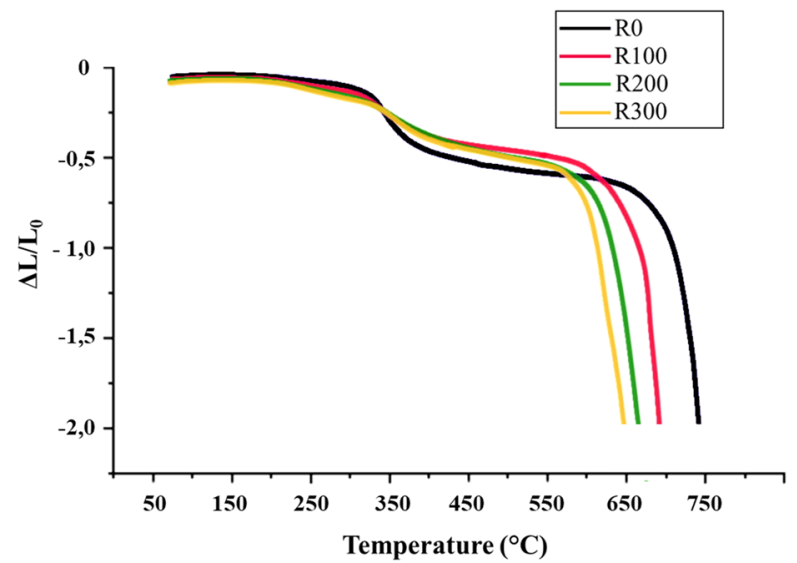

Fig. 11 Thermodilatometric behavior of geopolymeric samples prepared with waste dolomite refractory powder having maximum size of $250 \mu \mathrm{m}$ geopolymers, have little effect on the sample's melting temperature, prevailing the influence of the geopolymeric matrix. This is reasonably due to the particular chemical composition of the geopolymeric matrix which is placed in the area of the ternary diagram $\mathrm{Al}_{2} \mathrm{O}_{3}-\mathrm{SiO}_{2}-\mathrm{Na}_{2} \mathrm{O}$ where are present three ternary eutectic temperatures, respectively, 760,732 , and $740{ }^{\circ} \mathrm{C}[59]$. The gap between the above eutectics and the softening temperatures measured in the present research is due to the non-equilibrium conditions of the thermodilatometric tests which therefore reveal higher values but it is clear that the addition of waste dolomite refractory reduces refractoriness of the geopolymeric blank matrix. The above results are partially in conflict with those obtained by other researchers who demonstrated that alkali-activated geopolymers may have a thermal stability up to $1000{ }^{\circ} \mathrm{C}$ [60-63]. The difference is reasonably due to the different chemical composition, namely the $\mathrm{Si} / \mathrm{Al}, \mathrm{Na}_{2} \mathrm{O} / \mathrm{Al}_{2} \mathrm{O}_{3}$ ratios of the geopolymer investigated.

Figure 12 shows the changes occurring in FTIR spectra on the reference sample after exposure to high temperatures.
Table 4 Samples' shrinkages and softening temperature measured during the thermodilatometric tests

\begin{tabular}{lllll}
\hline Sample name & $\begin{array}{l}\text { Total shrinkage } \\
(\%)\end{array}$ & $\begin{array}{l}\text { Starting sintering } \\
\text { temperature }\left({ }^{\circ} \mathrm{C}\right)\end{array}$ & $\begin{array}{l}\text { Shrinkage between } 170 \\
\text { and } 400{ }^{\circ} \mathrm{C}(\%)\end{array}$ & $\begin{array}{l}\text { Softening } \\
\text { temperature } \\
\left({ }^{\circ} \mathrm{C}\right)\end{array}$ \\
\hline R0 & 1.9 & 700 & 0.1 & 750 \\
R100 & 2.1 & 650 & 0.1 & 700 \\
R200 & 2.0 & 610 & 0.1 & 670 \\
R300 & 2.1 & 600 & 0.1 & 660 \\
\hline
\end{tabular}
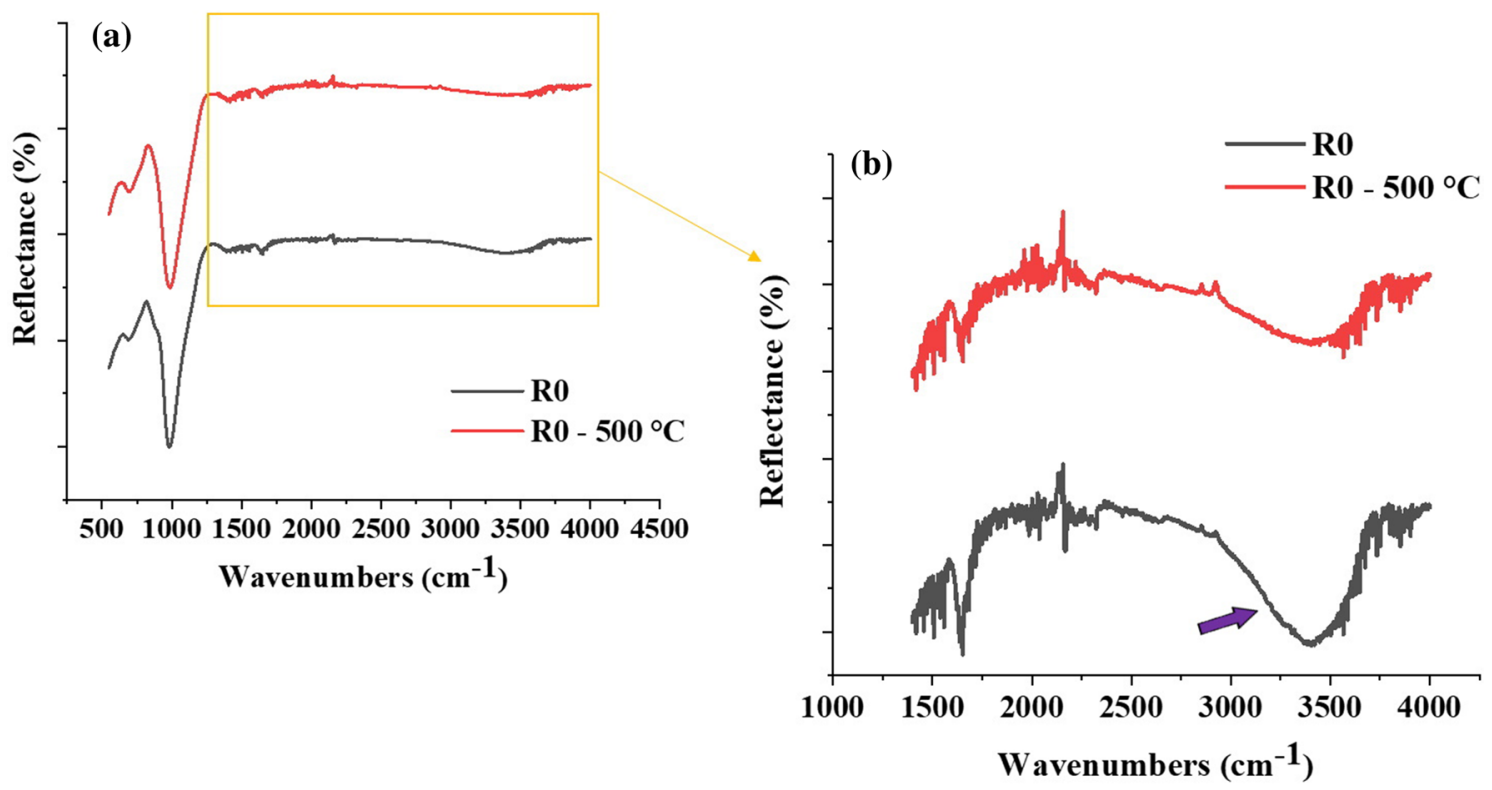

Fig. 12 ATR-FTIR spectra collected on a reference sample before and after heating at $500{ }^{\circ} \mathrm{C}$ (a). Details of a spectral windows ranging from 1400 to $4000 \mathrm{~cm}^{-1}$ (b). The main vibrations are indicated by arrows 
The detail in panel (b) highlights the intensity decreasing in the band located at $3250 \mathrm{~cm}^{-1}$. This band arises from to the $\mathrm{O}-\mathrm{H}$ bonds from water which are removed after heating and no other crystallographic changes were observed. For the sake of brevity, the FTIR spectra of the other compositions are not reported in the present paper, but material's dehydroxylation is the only crystallographic change which has been observed, in the present research, as a consequence of the thermal treatment up to $500{ }^{\circ} \mathrm{C}$ in line with the results obtained by other authors $[64,65]$.

\section{Conclusions}

Metakaolin, waste dolomite refractories, sodium silicate solution, and $8 \mathrm{M}$ sodium hydroxide solution were mixed in order to prepare several geopolymers. The as-received waste refractories were previously crumbled and then transformed into powdered products which were shared into batches having three maximum particles dimensions namely $250 \mu \mathrm{m}, 1$ $\mathrm{mm}$. and $2.5 \mathrm{~mm}$. Each batch was added, in different proportions, to the geopolymeric matrix.

It was observed that

- The addition of powdered waste refractory reduces slurries workability but, after hardening, improves the compressive strength with respect to the reference composition;

- Samples containing particles with maximum sizes of 1 $\mathrm{mm}$ and $2.5 \mathrm{~mm}$ do not maintain integrity after hardening and they are fractured as a consequence of significant volumetric instabilities;

- During the geopolymeric reaction quartz (present in MK) and calcium carbonate (from waste refractory) behave as inert components;

- Muscovite (from MK), pyroaurite, brushite, portlandite, and periclase (from waste refractory) display a certain degree of reactivity thus disclosing their contribute to the build up of the geopolymeric network;

- The highest compressive strength was measured in composition R100, whereas higher or lower R additions lead to materials with inferior strength;

- Specific surface area of all the samples seems to be independent of materials composition, whereas pore volume slightly increases with the amount of waste dolomite refractory;

- During the thermodilatometric tests, all compositions display a shrinkage of about $0.1 \%$ between 170 and $400{ }^{\circ} \mathrm{C}$, but sintering starts at higher temperature (above $600{ }^{\circ} \mathrm{C}$ ) and samples melt at temperatures ranging from 650 to $750{ }^{\circ} \mathrm{C}$ as a function of their composition.
Funding Open access funding provided by Università degli Studi di Udine within the CRUI-CARE Agreement.

\section{Declaration}

Conflict of interest The authors declare that they have no known competing financial interests or personal relationships that could have appeared to influence the work reported in this paper.

Open Access This article is licensed under a Creative Commons Attribution 4.0 International License, which permits use, sharing, adaptation, distribution and reproduction in any medium or format, as long as you give appropriate credit to the original author(s) and the source, provide a link to the Creative Commons licence, and indicate if changes were made. The images or other third party material in this article are included in the article's Creative Commons licence, unless indicated otherwise in a credit line to the material. If material is not included in the article's Creative Commons licence and your intended use is not permitted by statutory regulation or exceeds the permitted use, you will need to obtain permission directly from the copyright holder. To view a copy of this licence, visit http://creativecommons.org/licenses/by/4.0/.

\section{References}

1. Davidovits J (1991) Geopolymers-inorganic polymeric new materials. J Therm Anal 37(8):1633-1656

2. Davidovits J (1994) Geopolymers: man-made rock geosynthesis and the resulting development of very early high strength cement. J Mater Educ 16:91-139

3. Duxson P, Provis JL, Lukey GC, van Deventer JSJ (2007) The role of inorganic polymer technology in the development of 'green concrete'. Cement Concrete Res. https://doi.org/10.1016/j.cemco nres.2007.08.018

4. Puertas F, González-Fonteboa B, González-Taboada I, Alonso MM, Torres-Carrasco M, Rojo G, Martínez-Abella F (2018) Alkali-activated slag concrete: fresh and hardened behaviour. Cement Concr Compos. https://doi.org/10.1016/j.cemconcomp. 2017.10.003

5. Abdollahnejad Z, Pacheco-Torgal F, Aguiar JB, Jesus C (2015) Durability performance of fly ash based one-part geopolymer mortars. Key Eng Mater. https://doi.org/10.4028/www.scientific. net/KEM.634.113

6. Abdalqader AF, Jin F, Al-Tabbaa A (2016) Development of greener alkali-activated cement: utilisation of sodium carbonate for activating slag and fly ash mixtures. J Clean Prod. https://doi. org/10.1016/j.jclepro.2015.12.010

7. Habert G, De Lacaillerie JDE, Roussel N (2011) An environmental evaluation of geopolymer based concrete production: reviewing current research trends. J Clean Prod. https://doi.org/ 10.1016/j.jclepro.2011.03.012

8. Grant Norton M, Provis JL (2020) 1000 at 1000: geopolymer technology - the current state of the art. J Mater Sci. https://doi.org/ $10.1007 / \mathrm{s} 10853-020-04990-\mathrm{z}$

9. Adesanya E, Ohenoja K, Kinnunen P, Illikainen M (2017) Alkali activation of ladle slag from steel-making process. J Sustain Metall. https://doi.org/10.1007/s40831-016-0089-x

10. Ke X, Bernal SA, Ye N, Provis JL, Yang J (2015) One-part geopolymers based on thermally treated red Mud/ $\mathrm{NaOH}$ blends. J Am Ceram Soc. https://doi.org/10.1111/jace.13231

11. Ye N, Yang J, Liang S, Hu Y, Hu J, Xiao B, Huang Q (2016) Synthesis and strength optimization of one-part geopolymer based 
on red mud. Constr Build Mater. https://doi.org/10.1016/j.conbu ildmat.2016.02.099

12. Li F, Liu L, Yang Z, Li S (2021) Physical and mechanical properties and micro characteristics of fly ash-based geopolymer paste incorporated with waste Granulated Blast Furnace Slag (GBFS) and functionalized Multi-Walled Carbon Nanotubes (MWCNTs). J Hazard Mater. https://doi.org/10.1016/j.jhazmat.2020.123339

13. Matsuda A, Maruyama I, Meawad A, Pareek S, Araki Y (2019) Reaction, phases, and microstructure of fly ash-based alkali-activated materials. J Adv Concrete Technol. https://doi.org/10.3151/ jact.17.93

14. Ismail I, Bernal SA, Provis JL, San Nicolas R, Hamdan S, van Deventer JSJ (2014) Modification of phase evolution in alkaliactivated blast furnace slag by the incorporation of fly ash. Cement Concrete Comp. https://doi.org/10.1016/j.cemconcomp. 2013.09.006

15. Fernández-Jiménez A, Palomo A, Sobrados I, Sanz J (2006) The role played by the reactive alumina content in the alkaline activation of fly ashes. Microporous Mesoporous Mater. https://doi.org/ 10.1016/j.micromeso.2005.11.015

16. Criado M, Fernández-Jiménez A, Palomo A (2007) Alkali activation of fly ash: effect of the $\mathrm{SiO}_{2} / \mathrm{Na}_{2} \mathrm{O}$ ratio. Part I: FTIR study. Microporous Mesoporous Mater. https://doi.org/10.1016/j.micro meso.2007.02.055

17. Rodríguez ED, Bernal SA, Provis JL, Paya J, Monzo JM, Borrachero MV (2013) Effect of nanosilica-based activators on the performance of an alkali-activated fly ash binder. Cement Concrete Comp. https://doi.org/10.1016/j.cemconcomp.2012.08.025

18. Hlaváček P, Šmilauer V, Škvára F, KopeckyŠulc ĹR (2015) Inorganic foams made from alkali-activated fly ash: mechanical, chemical and physical properties. J Eur Ceram Soc. https://doi. org/10.1016/j.jeurceramsoc.2014.08.024

19. Toniolo N, Boccaccini AR (2017) Fly ash-based geopolymers containing added silicate waste: a review. Ceram Int. https://doi. org/10.1016/j.ceramint.2017.07.221

20. Gebregziabiher BS, Thomas R, Peethamparan S (2015) Very early-age reaction kinetics and microstructural development in alkali-activated slag. Cement Concrete Comp. https://doi.org/10. 1016/j.cemconcomp.2014.09.001

21. Panagiotopoulou Ch, Kontori E, Perraki Th, Kakali G (2007) Dissolution of aluminosilicate minerals and by-products in alkaline media. J Mater Sci. https://doi.org/10.1007/s10853-006-0531-8

22. Phair JW, van Deventer JSJ (2001) Effect of silicate activator $\mathrm{pH}$ on the leaching and material characteristics of waste-based inorganic polymers. Miner Eng. https://doi.org/10.1016/S08926875(01)00002-4

23. Mozgawa W, Deja J (2009) Spectroscopic studies of alkaline activated slag geopolymers. J Mol Struct. https://doi.org/10.1016/j. molstruc.2008.12.026

24. Kuenzel C, Ranjbar N (2019) Dissolution mechanism of fly ash to quantify the reactive aluminosilicates in geopolymerisation. Resour Conserv Recycl. https://doi.org/10.1016/j.resconrec.2019. 104421

25. Nath SK (2020) Fly ash and zinc slag blended geopolymer: immobilization of hazardous materials and development of paving blocks. J Hazard Mater. https://doi.org/10.1016/j.jhazmat.2019. 121673

26. Lun Y, Zhou MK, Cai X, Xu F (2008) Methods for improving volume stability of steel slag as fine aggregate. J Wuhan Univ Technol. https://doi.org/10.1007/s11595-007-5737-3

27. Kuhn M, Drissen P, Geiseler J, Schrey HJ (1997) A new BOF slag treatment technology. In: Proceedings of the 2nd European oxygen steel making congress, pp 445-453.

28. Shigeru M, Hirohi K, Keiichi K (1997) The development of the new ageing process of steel-making slag. SEAISI Q 26:37-48
29. Fleischanderl A, Gennari U, Ilie A (2004) ZEWA—metallurgical process for treatment of residues from steel industry and other industrial sectors to generate valuable products. Ironmak Steelmak. https://doi.org/10.1179/irs.2004.31.6.444

30. Shi C, Hu S (2003) Cementitious properties of ladle slag fines under autoclave curing conditions. Cement Concrete Res. https:// doi.org/10.1016/S0008-8846(03)00211-4

31. Chen M, Zhou MK, Wu S (2007) Optimization of blended mortars using steel slag sand. J Wuhan Univ Technol. https://doi.org/10. 1007/s11595-006-4741-3

32. Furlani E, Maschio S (2016) Long term compression strength of mortars produced using coarse steel slag as aggregate. Adv Civil Eng. https://doi.org/10.1155/2016/3431249

33. Faraone N, Tonello G, Furlani E, Maschio S (2009) Steelmaking slag as aggregate for mortars: effects of particle dimension on compression strength. Chemosphere. https://doi.org/10.1016/j. chemosphere.2009.08.002

34. Maschio S, Aneggi E, Fedrizzi L, Andreatta F, Lekka M, Lanzutti A, Furlani E (2017) Production and compression strength of mortars containing unprocessed waste powdered steel slag. Sustainability. https://doi.org/10.3390/su9122372

35. Furlani E, Magnan M, Mingone E, Deison M, Aneggi E, Andreatta F, Fedrizzi L, Maschio S (2019) Waste olivine and silica sands boost geopolymers performances: experimental investigation. Int J Environ Stud. https://doi.org/10.1080/00207233.2019. 1585156

36. Jenkins R, Snyder R (1996) Introduction to X-ray powder diffractometry. Wiley, New York

37. Wang Q, Li L, Wu CP, Sui ZT (2009) Research on adaptability of slag-based geopolymer with superplasticizer. Key Eng Mater. https://doi.org/10.4028/www.scientific.net/KEM.405-406.129

38. Nematollahi B, Sanjayan J (2014) Effect of different superplasticizers and activator combinations on workability and strength of fly ash based geopolymer. Mater Design. https://doi.org/10. 1016/j.matdes.2014.01.064

39. Cassidy JE (1977) Phosphate bonding then and now. Am Ceram Soc Bull 56(7):640-643

40. Kalyoncu RS (1982) Chemically bonded refractories-a review of the state of the art. Bureau of mines information circular, Washington, DC

41. Zhaoheng L, Wei Z, Ruilan W, Fangzhu C, Xichun J, Peitong $\mathrm{C}$ (2019) Effects of reactive $\mathrm{MgO}$ on the reaction process of geopolymer. Materials. https://doi.org/10.3390/ma12030526

42. Temuujin J, van Riessen A, Williams R (2009) Influence of calcium compounds on the mechanical properties of fly ash geopolymer pastes. J Hazard Mat. https://doi.org/10.1016/j.jhazm at.2008.12.121

43. Nedeljkovic M, Zuo YB, Arbi K, Ye G (2018) Carbonation resistance of alkali-activated slag under natural and accelerated conditions. J Sustain Metall. https://doi.org/10.1007/ s40831-018-0166-4

44. Yip CK, van Deventer JSJ (2003) Microanalysis of calcium silicate hydrate gel formed within a geopolymeric binder. J Mater Sci. https://doi.org/10.1023/A:1025904905176

45. Yip CK, Lukey GC, van Deventer JSJ (2005) The coexistence of geopolymeric gel and calcium silicate hydrate at early stage of alkaline activation. Cement Concrete Res. https://doi.org/10. 1016/j.cemconres.2004.10.042

46. Dombrowski K, Buchwald A, Weil M (2007) The influence of calcium content on the structure and thermal performance of fly ash based geopolymers. J Mater Sci. https://doi.org/10.1007/ s10853-006-0532-7

47. Ma W, Brown PW (1997) Hydrothermal reactions of fly ash with $\mathrm{Ca}(\mathrm{OH})_{2}$ and $\mathrm{CaSO}_{4} \cdot 2 \mathrm{H}_{2} \mathrm{O}$. Cement Concrete Res. https:// doi.org/10.1016/S0008-8846(97)00116-6 
48. Granizo ML, Alonso S, Blanco-Varela MT, Palomo A (2002) Alkaline activation of metakaolin: effect of calcium hydroxide in the products of reaction. J Am Ceram Soc 85:225-231

49. Lee Y, Kang S (2016) Effect of the $\mathrm{CaO}$ content on microstructure and mechanical strength of fly Ash-based geopolymer. Contem Eng Sci. https://doi.org/10.12988/ces.2016.69158

50. Tchakouté HK, Rüscher CH (2017) Mechanical and microstructural properties of metakaolin-based geopolymer cements from sodium waterglass and phosphoric acid solution as hardeners: a comparative study. Appl Clay Sci. https://doi.org/10.1016/j. clay.2017.02.002

51. Louati S, Hajjaji W, Baklouti S, Samet B (2014) Structure and properties of new eco-material obtained by phosphoric acid attack of natural Tunisian clay. Appl Clay Sci. https://doi.org/ 10.1016/j.clay.2014.07.015

52. Rovnaník P (2010) Effect of curing temperature on the development of hard structure of metakaolin-based geopolymer. Constr Build Mater. https://doi.org/10.1016/j.conbuildmat.2009.12.023

53. Garcia-Lodeiro I, Palomo A, Fernández-Jiménez A, Macphee DE (2011) Compatibility studies between NASH and CASH gels. Study in the ternary diagram $\mathrm{Na}_{2} \mathrm{O}-\mathrm{CaO}-\mathrm{Al}_{2} \mathrm{O}_{3}-\mathrm{SiO}_{2}-\mathrm{H}_{2} \mathrm{O}$. Cement Concrete Res. https://doi.org/10.1016/j.cemconres.2011. 05.006

54. Król M, Rożek P, Chlebda D, Mozgawa W (2018) Influence of alkali metal cations/type of activator on the structure of alkaliactivated fly ash-ATR-FTIR studies. Spectrochim Acta Part A. https://doi.org/10.1016/j.saa.2018.02.067

55. Duxson P, Provis JL, Lukey GC, Mallicoat SW, Kriven WM, van Deventer JSJ (2005) Understanding the relationship between geopolymer composition, microstructure and mechanical properties. Colloids Surf A. https://doi.org/10.1016/j.colsurfa.2005.06.060

56. Henon J, Alzina A, Absi J, Smith DS, Rossignol S (2012) Porosity control of cold consolidated geomaterial foam: temperature effect. Ceram Int. https://doi.org/10.1016/j.ceramint.2011.06.040

\section{Authors and Affiliations}

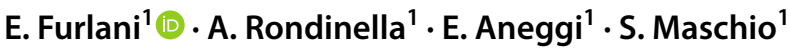

\author{
A. Rondinella \\ alfredo.rondinella@uniud.it \\ E. Aneggi \\ eleonora.aneggi@uniud.it \\ S. Maschio \\ stefano.maschio@uniud.it
}

57. Ismail I, Bernal SA, Provis JL, Hamdan S, van Deventer JSJ (2013) Drying-induced changes in the structure of alkali-activated pastes. J Mater Sci. https://doi.org/10.1007/s10853-013-7152-9

58. Strozi Cilla M, Colombo P, Raymundo Morelli M (2014) Geopolymer foams by gelcasting. Ceram Int. https://doi.org/10.1016/j. ceramint.2013.11.011

59. Osborne EF, Muan A (1960) Phase equilibrium diagram of oxide system, plate 4, system $\mathrm{Al}_{2} \mathrm{O}_{3}-\mathrm{Na}_{2} \mathrm{O}-\mathrm{SiO}_{2}$, Fig 501. Am. Ceram. Soc. And the Edward Orton Jr. Ceramic Foundation, Westerville

60. Duxson P, Lukey GC, van Deventer JSJ (2006) Thermal evolution of metakaolin geopolymers: Part 1-Physical evolution. J NonCryst Solids. https://doi.org/10.1016/j.jnoncrysol.2006.09.019

61. Duxson P, Lukey GC, van Deventer JSJ (2007) Thermal evolution of metakaolin geopolymers: Part 2-Phase stability and structural development. J Non-Cryst Solids. https://doi.org/10.1016/j.jnonc rysol.2007.02.050

62. Cheng TW, Chiu JP (2003) Fire-resistant geopolymer produced by granulated blast furnace slag. Miner Eng. https://doi.org/10. 1016/S0892-6875(03)00008-6

63. Abdel-Ghani NT, El Sayed HA, Moied SA (2018) Geopolymer synthesis by the alkali-activation of blast furnace steel slag and its fire-resistance. HBRC J. https://doi.org/10.1016/j.hbrcj.2016. 06.001

64. Oudadesse H, Derrien AC, Lefloch M, Davidovits J (2007) MAS-NMR studies of geopolymers heat-treated for applications in biomaterials field. J Mater Sci. https://doi.org/10.1007/ s10853-006-0524-7

65. Sayeda M, Gadoa RA, Nagaa SM, Colombo P, Elsayed H (2020) Influence of the thermal treatment on the characteristics of porous $\mathrm{T}$ geopolymers as potential biomaterials. Mat Sci Eng C. https:// doi.org/10.1016/j.msec.2020.111171

Publisher's Note Springer Nature remains neutral with regard to jurisdictional claims in published maps and institutional affiliations.
1 Polytechnic Department of Engineering and Architecture, University of Udine, Via Del Cotonificio 108, 33100 Udine, Italy 